\title{
The Impact Resistance of Highly Densified Metal Alloys Manufactured from Gas-Atomized Pre-Alloyed Powders
}

\author{
Ramin Rahmani ${ }^{1,2, *}$, Maksim Antonov ${ }^{1}$ (D) and Konda Gokuldoss Prashanth 1,3,4 $^{(D)}$ \\ 1 Department of Mechanical and Industrial Engineering, Tallinn University of Technology, Ehitajate tee 5, \\ 19086 Tallinn, Estonia; maksim.antonov@taltech.ee (M.A.); prashanth.konda@taltech.ee (K.G.P.) \\ 2 Laboratory for Nonlinear Mechanics, Faculty of Mechanical Engineering, University of Ljubljana, \\ Askerceva 6, SI-1000 Ljubljana, Slovenia \\ 3 Erich Schmid Institute of Materials Science, Austrian Academy of Science, Jahnstraße 12, \\ A-8700 Leoben, Austria \\ 4 CBCMT, School of Mechanical Engineering, Vellore Institute of Technology, Tamil Nadu 632014, India \\ * Correspondence: ramin.rahmaniahranjani@gmail.com or ramin.rahmaniahranjani@taltech.ee; \\ Tel.: +37-251988504
}

Citation: Rahmani, R.; Antonov, M.; Prashanth, K.G. The Impact

Resistance of Highly Densified Metal Alloys Manufactured from Gas-Atomized Pre-Alloyed Powders. Coatings 2021, 11, 216. https:// doi.org/10.3390/coatings11020216

Academic Editor: Dana Ashkenazi

Received: 13 January 2021

Accepted: 9 February 2021

Published: 12 February 2021

Publisher's Note: MDPI stays neutral with regard to jurisdictional claims in published maps and institutional affiliations.

Copyright: (c) 2021 by the authors. Licensee MDPI, Basel, Switzerland. This article is an open access article distributed under the terms and conditions of the Creative Commons Attribution (CC BY) license (https:// creativecommons.org/licenses/by/ $4.0 /)$.

\begin{abstract}
With the increasing acceleration of three-dimensional (3D) printing (for example, powder bed fusion (PBF)) of metal alloys as an additive manufacturing process, a comprehensive characterization of 3D-printed materials and structures is inevitable. The purpose of this work was to test highly densified materials produced from gas-atomized pre-alloyed metallic powders, namely $316 \mathrm{~L}, \mathrm{Ti}_{6} \mathrm{Al}_{4} \mathrm{~V}, \mathrm{AlSi}_{10} \mathrm{Mg}, \mathrm{CuNi}_{2} \mathrm{SiCr}, \mathrm{CoCr}_{28} \mathrm{Mo}_{6}$, and Inconel718, under impact conditions. This was done to demonstrate the best possible performance of such materials. Optimized spark plasma sintering (SPS) parameters (pressure, temperature, heating rate, and holding time) are applied as a novel technique of powder metallurgy. The densification level, impact site (imprint) diameter and volume, and Vickers hardness were studied. The comparison of 316L stainless steel (1) sintered by the SPS process, (2) manufactured by PBF process, and (3) coated by the physical vapor deposition (PVD) process (thin layer of TiAlN) was successfully achieved.
\end{abstract}

Keywords: additive manufacturing; selective laser melting; powder bed fusion; powder metallurgy; spark plasma sintering; metallic alloys; physical vapor deposition

\section{Introduction}

In powder metallurgy (PM), minimizing the grain growth (in comparison to conventional PM methods) to control the densification/consolidation is possible using a spark plasma sintering (SPS) device to control the ramp rate, sintering temperature, pressure, and time. The main parts used for the consolidation of materials during SPS are schematically illustrated in Figure 1. SPS is a PM sintering technique including a uniaxial press, graphite punches, vacuum chamber (possible with flow of nitrogen), thermocouple or pyrometer controlling, pulsed direct current generator, and cooling system surrounding the chamber [1]. In the current study, the primary heating mechanism was Joule heating, which is based on heat generation in the case of conductive materials and metals due to resistance to electric current. The graphite sheet/foil rolled in between the graphite die/mold and powders (also applied in the top and down, between the punch and powders) was used to facilitate the sintering of the powders [2].

The powder characteristics are a vast area, at least including production technology, density, size, melting point, particle shape, flowability, and thermal/electrical conductivity. [3]. The most commonly used metal(s) and their alloys in the 3D printing field include $\mathrm{Fe}, \mathrm{Ti}, \mathrm{Al}, \mathrm{Cu}, \mathrm{Co}$, and Ni. Since the selective laser melting (SLM) process has become a novel Addictive manufacturing (AM) and powder bed fusion (PBF) technology based on the repeated sweeping of, for example, 316L powder in the manufacturing chamber on top 
of previously melted layers in every sequence of recoater movement, the fabricated surface may have some defects and pores. The defective layer can be improved during sintering of the next layer of powders $[4,5]$. $\mathrm{Ti}_{6} \mathrm{Al}_{4} \mathrm{~V}$ is an $\alpha+\beta$ titanium martensitic microstructure alloy widely used in the aerospace and biomedical industries, along with 316L, due to its excellent mechanical, chemical, biocompatible, and lightweight character [6-8].

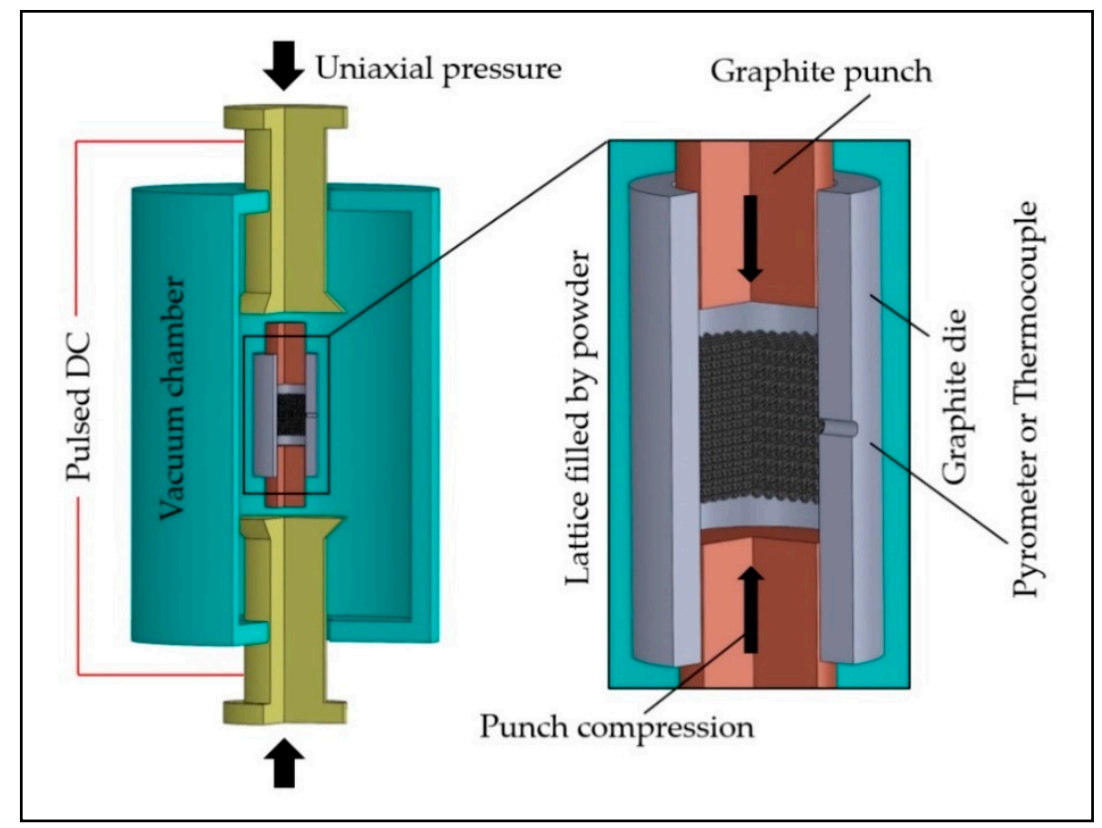

Figure 1. Schematic of spark plasma sintering device (SPS, SolidWorks design).

The AM technique and its subset, three-dimensional (3D) printing, is an approach for the rapid prototyping of a wide range of metals and ceramics, complex geometries and structures, and small or large size objects in form of lattice or solid directly produced from the computer-aided model (CAD). The fabrication process includes layer-by-layer material deposition that is built as layer $n$th on top of layer $(n-1)$ th [9]. Additive manufacturing is characterized by minor postprocessing, treatment by cutting tools, need for additional fixture preparation, intermediate process control steps, etc. [10]. During the SLM process, as the most popular laser powder bed fusion (L-PBF) technology (standardized as ASTM F2792), an object is melted by the laser beam and formed on top of the printer platform/baseplate by sweeping the successive layers of powders [11]. SLM is a repetitive process, with a supply of power feeding the manufacturing platform, the consolidation of an object by laser scanning, heating up over the surface resulting in layer deposition on previously consolidated layers, and cooling during the fabrication of the following layers [12]. Scanning speed, laser current, and layer thickness have a crucial role as PBF process parameters. The schematic of selective laser melting device for lattice/scaffold fabrication sketched by SolidWorks is shown in Figure 2.

Al-Si alloys are known for their good weldability, castability, corrosion resistance, conductivity, and light weight, and can be highly interesting for bionic aerospace and automotive applications. The addition of $\mathrm{Mg}$ alloying element to this composition improves its strength and dynamic toughness significantly [13]. Due to light reflection and thermal/electrical conductivity of pure copper, both processing and postprocessing are challenging. CuNiSi alloys expect to satisfy adequate tensile strength and electrical conductivity because of Si content. However, alloying of copper with Sn, reduces the electrical conductivity and enhance the corrosion resistance (such as $\mathrm{CuSn}_{4}, \mathrm{CuSn}_{8}$, or $\mathrm{CuSn}_{10}$ powders alloys) [14]. 


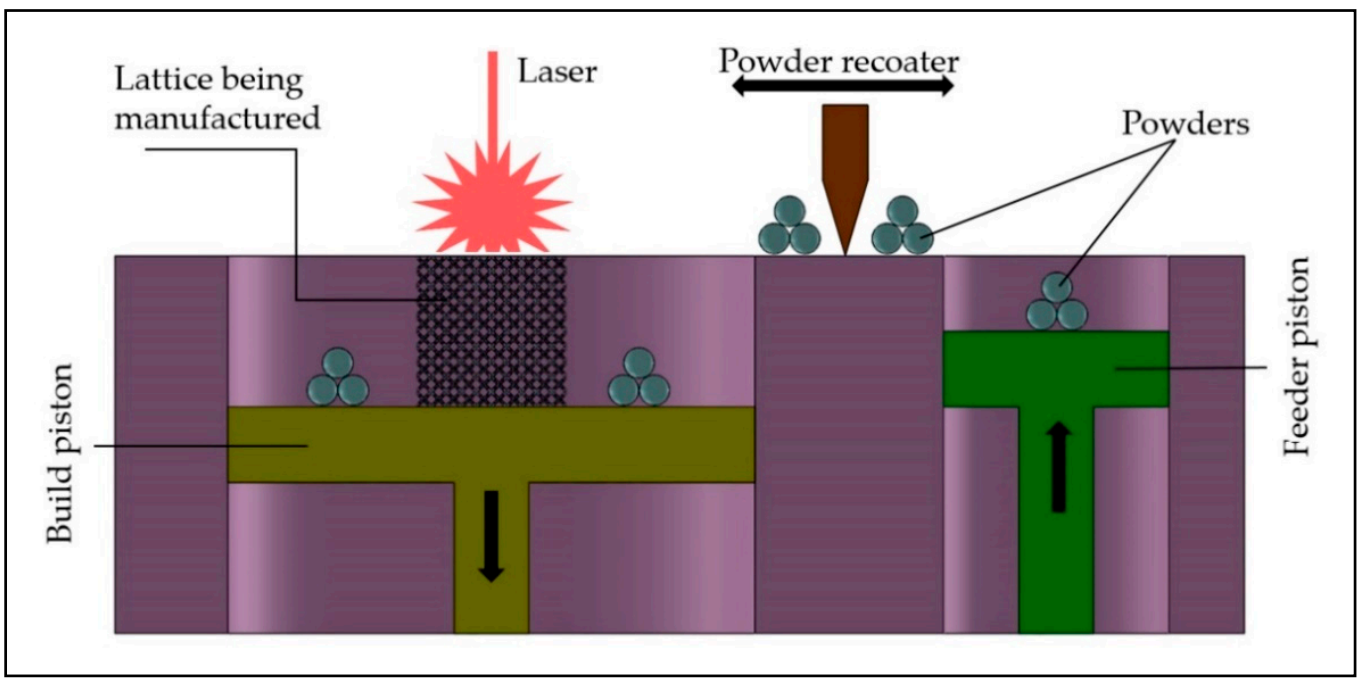

Figure 2. Schematic of selective laser melting device (SLM, SolidWorks design).

CoCrMo alloys are commonly used for dental replacements and restorations, including crowns, screws, and bridges in the posterior region. The highest priorities in this field are related to life expectancy, corrosion resistance, impact resistance, and biocompatibility [15]. The extreme enhancement of corrosion resistance while, at the same time, keeping the biocompatibility and coating properties, can be supplied by adding gas-atomized and pre-alloyed tungsten to this alloy. For example, both Co-based Starbond CoS 55 [16] or Fe-based Rockit 701 [17] powders are available with $9.5 \mathrm{wt} . \%$. W. Inconel718 is a known superalloy (such as Inconel625 and Inconel939), and nickel-based alloys are used for the turbines, blades, shafts, etc., as well as in SLM processes. Nickel-based alloys are suitable for welding, fatigue, creep, and high-temperature applications (due to the low content of titanium and aluminum) [18]. The CAD-based design for additive manufacturing (DfAM) and finite element analysis (FEA) is a time- and cost-efficient way to predict either mechanical behaviors of alloys or composites or provide an optimal selection of the material regarding the application by CAD design and/or FEA multiphysics software, e.g., SolidWorks, Ansys, and/or Comsol [19-21].

SPS-built objects can be introduced as a criterion for SLM-built solid samples. (however, it is feasible for simple shapes, e.g., disks and cubes; for complex or porous shapes, hot isostatic pressing (HIP) can be an option). During the 3D printing process, depending on powder character (metals, ceramics, cements, composites, etc.), some powder particles could be agglomerated (in the vicinity of the printed part) or their properties can be changed (due to overheating, for example). Powder particles can be introduced into the build zone during the next whipping that can reduce precision or deteriorate the properties of the produced part. Six bulk metal alloys encompassing Fe-, $\mathrm{Ti}-$, $\mathrm{Al}-, \mathrm{Cu}-, \mathrm{Co}-$, and Ni-based were manufactured by the SPS process and tested using the hammering impact test. Samples produced by the SLM technique sometimes have high porosity (in the case of ceramics and/or composites in comparison with subtractive manufacturing and modern powder metallurgy routes), but it can be controlled by layer thickness, optimized laser power, and scan speed in case of metal alloys. However, the controlled porosity/permeability can be applied as an advantage for the delivery of antibiotics and bone healing in the tissue engineering field.

The current study aimed to produce the samples from gas-atomized, pre-alloyed, and spherical-shaped powders (applicable for AM and PBF technologies) with high densification levels to demonstrate their possible best performance. Sintering parameters were applied to fabricate and compare samples with the same appearance of SLM production (dimension and densification). Considering the expensive and time-consuming processing of AM, the present approach allowed us to fairly estimate the specification of solid objects subjected to mechanical tests. Comparison of most used metallic alloys in $\mathrm{PBF}\left(\mathrm{Ti}_{6} \mathrm{Al}_{4} \mathrm{~V}\right.$, 
AlSi10Mg, CuNi2SiCr, CoCr28Mo6, and Inconel718) with stainless steel 316L (sintered by the SPS process, manufactured by the SLM/PBF process, and coated by the PVD process) under the dynamic impact test was successfully achieved in the present work. The impact resistance of alloys is defined by the measurement of mechanical characterization, such as densification level, deformation site, indented volume, acceleration value in the test region.

\section{Materials and Methods}

Densification of samples depend on many parameters, such as powder size and shape, distribution of size and shape, phase change and grain growth of powders in the sintering mold, etc. It is inevitable for a gas atomization process to reach high purity, quality, homogeneity, and flowability of spherical powder/particle production for AM/PBF applications. In this procedure, alloying elements were added to the molten balanced metal before the gas atomization process. SEM micrographs of gas-atomized pre-alloyed metallic powders Fe-based 316L, Ti-based $\mathrm{Ti}_{6} \mathrm{Al}_{4} \mathrm{~V}$, Al-based AlSi ${ }_{10} \mathrm{Mg}$, Cu-based CuNi ${ }_{2} \mathrm{SiCr}$, Co-based $\mathrm{CoCr}_{28} \mathrm{Mo}_{6}$, and Ni-based Inconel718 are shown in Figure 3. The supplier [22-24], powder size, and alloy density are shown in Table 1. The SPS device, supplied by FCT Systeme $\mathrm{GmbH}$ (Frankenblick, Germany) [25], was installed inside the nitrogen glovebox to avoid oxidation. The alloys were consolidated at $50 \mathrm{MPa}$ pressure in $20 \mathrm{~mm}$ (diameter) graphite mold, with $100{ }^{\circ} \mathrm{C} / \mathrm{min}$ heating rate and $5 \mathrm{~min}$ holding time at sintering temperature. The sintered/produced samples, after sintering and slight polishing (polished by P800 sandpaper to remove the graphite sheet from both sides of disk-shaped samples), were $20 \mathrm{~mm}$ in diameter and $10 \mathrm{~mm}$ in height.
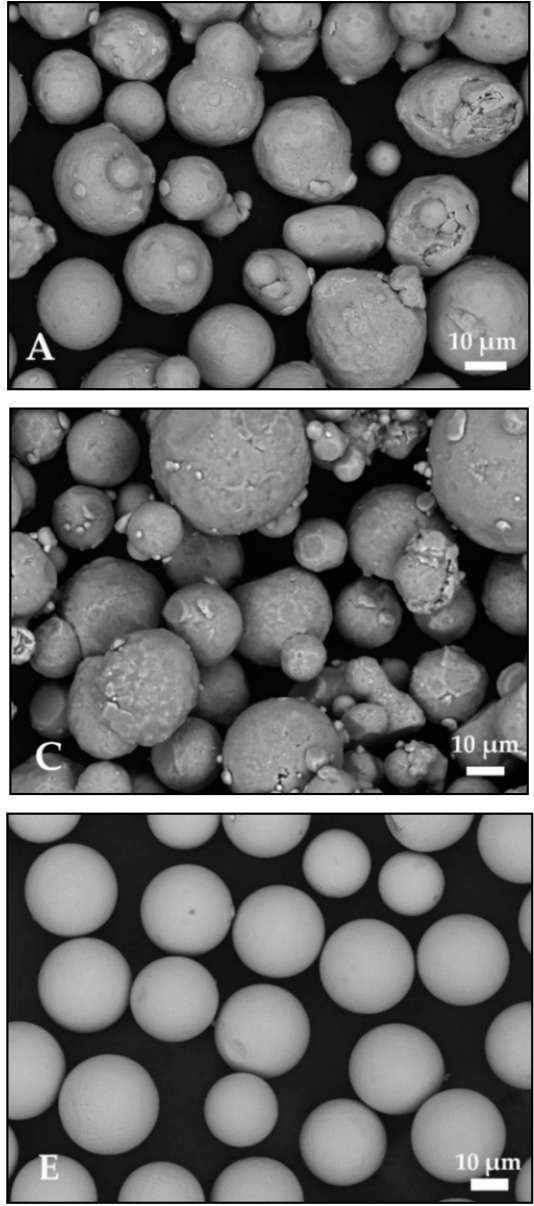
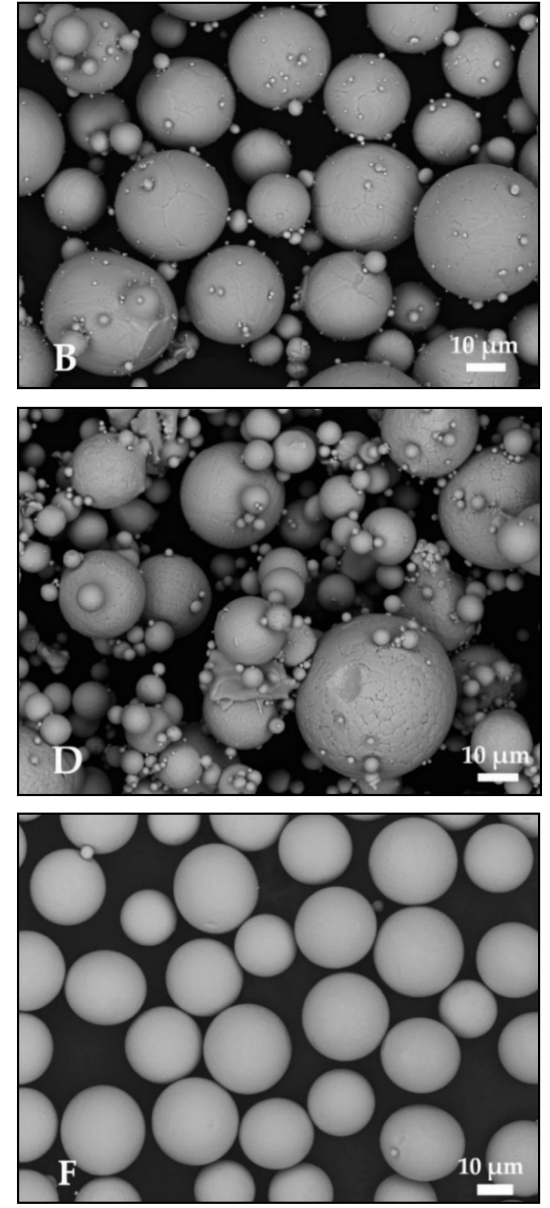

Figure 3. SEM micrograph of metallic alloy powders: (A) Fe-based 316L, (B) Ti-based $\mathrm{Ti}_{6} \mathrm{Al}_{4} \mathrm{~V},(\mathbf{C}) \mathrm{Al}-\mathrm{based} \mathrm{AlSi}{ }_{10} \mathrm{Mg}$, (D) Cu-based $\mathrm{CuNi}_{2} \mathrm{SiCr}$, (E) Co-based $\mathrm{CoCr}_{28} \mathrm{Mo}_{6}$, and (F) Ni-based Inconel718. 
Table 1. Metallic alloys specification: Supplier companies, density, composition, and sintering temperature. All samples were made at $50 \mathrm{MPa}$ pressure, $20 \mathrm{~mm}$ graphite mold, $100{ }^{\circ} \mathrm{C} / \mathrm{min}$ heating rate (ramp rate), and $5 \mathrm{~min}$ holding in sintering temperature.

\begin{tabular}{|c|c|c|c|c|c|}
\hline Metal Alloys & Suppliers & Density & Powder Size & Composition & $\begin{array}{c}\text { Sintering } \\
\text { Temperature }\end{array}$ \\
\hline $316 \mathrm{~L}$ & $\begin{array}{l}\text { SLM Solutions AG } \\
\text { (Lübeck, Germany) }\end{array}$ & $7.95 \mathrm{~g} / \mathrm{cm}^{3}$ & $10-45 \mu \mathrm{m}$ & Fe-balance, $\mathrm{Cr}, \mathrm{Ni}$, Mo & $1000^{\circ} \mathrm{C}$ \\
\hline $\mathrm{Ti}_{6} \mathrm{Al}_{4} \mathrm{~V}$ & SLM Solutions AG & $4.43 \mathrm{~g} / \mathrm{cm}^{3}$ & $20-63 \mu \mathrm{m}$ & Ti-balance, Al, V & $950^{\circ} \mathrm{C}$ \\
\hline $\mathrm{AlSi}_{10} \mathrm{Mg}$ & $\begin{array}{c}\text { TLS Technik GmbH } \\
\text { (Bitterfeld-Wolfen, } \\
\text { Germany) }\end{array}$ & $2.59 \mathrm{~g} / \mathrm{cm}^{3}$ & $20-63 \mu \mathrm{m}$ & Al-balance, $\mathrm{Si}, \mathrm{Mg}$ & $480^{\circ} \mathrm{C}$ \\
\hline $\mathrm{CuNi}_{2} \mathrm{SiCr}$ & TLS Technik GmbH & $8.84 \mathrm{~g} / \mathrm{cm}^{3}$ & $10-63 \mu \mathrm{m}$ & Cu-balance, $\mathrm{Ni}, \mathrm{Si}, \mathrm{Cr}$ & $820^{\circ} \mathrm{C}$ \\
\hline $\mathrm{CoCr}_{28} \mathrm{Mo}_{6}$ & $\begin{array}{c}\text { Sino-Euro Ltd } \\
\text { (Shaanxi, China) }\end{array}$ & $4.96 \mathrm{~g} / \mathrm{cm}^{3}$ & $15-45 \mu \mathrm{m}$ & Co-balance, $\mathrm{Cr}, \mathrm{Mo}$ & $1000{ }^{\circ} \mathrm{C}$ \\
\hline Inconel718 & Sino-Euro Ltd & $4.77 \mathrm{~g} / \mathrm{cm}^{3}$ & $15-45 \mu \mathrm{m}$ & Ni-balance, $\mathrm{Cr}, \mathrm{Mo}, \mathrm{Nb}$ & $1000^{\circ} \mathrm{C}$ \\
\hline
\end{tabular}

High flowability, similarity in size, spherical shape, and high thermal conductivity of powders are preferable for the SLM process. However, during the SPS process, electric currents passed through all of the particles, and these parameters were less significant. The SLM process can be controlled by printed layer thickness, laser power, laser current, and laser speed. However, the main SPS process parameters are pressure, ramp rate, sintering temperature, and holding time. In SPS program control, grain growth and oxidation of metallic particles must be prevented during the sintering, whereas the extent of cooling in the SLM route can be controlled by time spent between the printing of layers. Based on experiences, we held and preheated the powers at $300{ }^{\circ} \mathrm{C}$ for $5 \mathrm{~min}$ and $5 \mathrm{MPa}$ pressure during the SPS process to reduce the possible humidity and other contaminations. Herein, the ramp rate (or heating rate) was $100{ }^{\circ} \mathrm{C} / \mathrm{min}$ for all samples, e.g., increasing the temperature from $300{ }^{\circ} \mathrm{C}$ (dehumidification point) to $1000{ }^{\circ} \mathrm{C}$ (sintering point) in $7 \mathrm{~min}$.

Note that the present paper focused only on SPS production. However, the method was validated here by comparing the consolidated 316L powders in both SLM and SPS processes. The aim was to present a "test method" for the assessment of SPS's or SLM's "highly densified" productions. The point that it was possible to increase the pressure of SPS higher than $100 \mathrm{MPa}$ and have $\approx 99.9 \%$ densification level, but the currently applied pressure was selected to obtain the samples closer to SLM output $(\approx 90-99 \%$ for metal alloys). It is possible to apply another PM technique instead of SPS (e.g., conventional pressing and sintering or metal injection molding (MIM)) and to substitute other PBF approaches instead of SLM (e.g., electron beam melting (EBM)).

\section{Results and Discussion}

The impact wear test with multiple dynamic strikes was designed and developed in the "Research Laboratory of Tribology and Materials Testing" at the Tallinn University of Technology [26,27]. The aforementioned produced rounded samples (disk shape with $20 \mathrm{~mm}$ diameter and $10 \mathrm{~mm}$ height), which were fixed rigidly to the platform and tested by applying 30 repetitive impacts with the energy of $5.6 \mathrm{~J}$ at $27.5 \mathrm{~Hz}$ frequency (at $1.1 \mathrm{~s}$ ) using a Makita hammer-drill through a $\mathrm{ZrO}_{2}$ ball (with $10 \mathrm{~mm}$ diameter, stabilized by $\mathrm{Y}_{2} \mathrm{O}_{3}$; supplied by Tosoh, Tokyo, Japan). The test was in situ monitored by a vibration sensor attached to the main platform with the help of a PCH-1420 (Denmark) analyzer. The load $(98.1 \mathrm{~N}, 10 \mathrm{~kg})$ was provided by the deadweight system as shown in Figure 4. The impact sites (indents) of metallic alloys and vibration graphs (acceleration of platform to which the sample is fixed) are shown in Figures 5 and 6, respectively.

The impact test was used as a method to assess the behavior of materials (damage) and energy spent in the contact zone between the ball and the sample. If no impact energy 
is consumed in the contact zone, then the acceleration of the platform/sample will be the highest. If energy is spent on (1) plastic, (2) elastic deformation, or (3) fracture of material, then the acceleration will be lower. The implemented test method can be used for a wide range of material types, such as ceramics or bioceramics, metal alloys, hard materials, and hybrid composites produced by SPS and/or SLM or other methods as additional characterization criteria [28-31]. The size of the indent can be used as an indication of "dynamic hardness." The larger diameter, depth, or volume of penetration shows the higher ductility (extent of plastic deformation).

The sample behavior during the impact depends also on changes in the surface layer of the material taking place in the contact area with the contacting ball. The $\mathrm{Al}$ - and $\mathrm{Cu}$ - based materials were ductile, with a wider diameter of the deformation site (see Figure 5C,D). In contrast, Fe and Ti alloys provided higher resistance against impact (see Figure 5A,B). The stated diameters are average ones, because in the case of stiff metal alloys, the deformed area may change from circle to oval shape (ball may slightly slide during the impact). Due to this phenomenon, deformation diameter should be considered along with the indented volume (see Table 2).
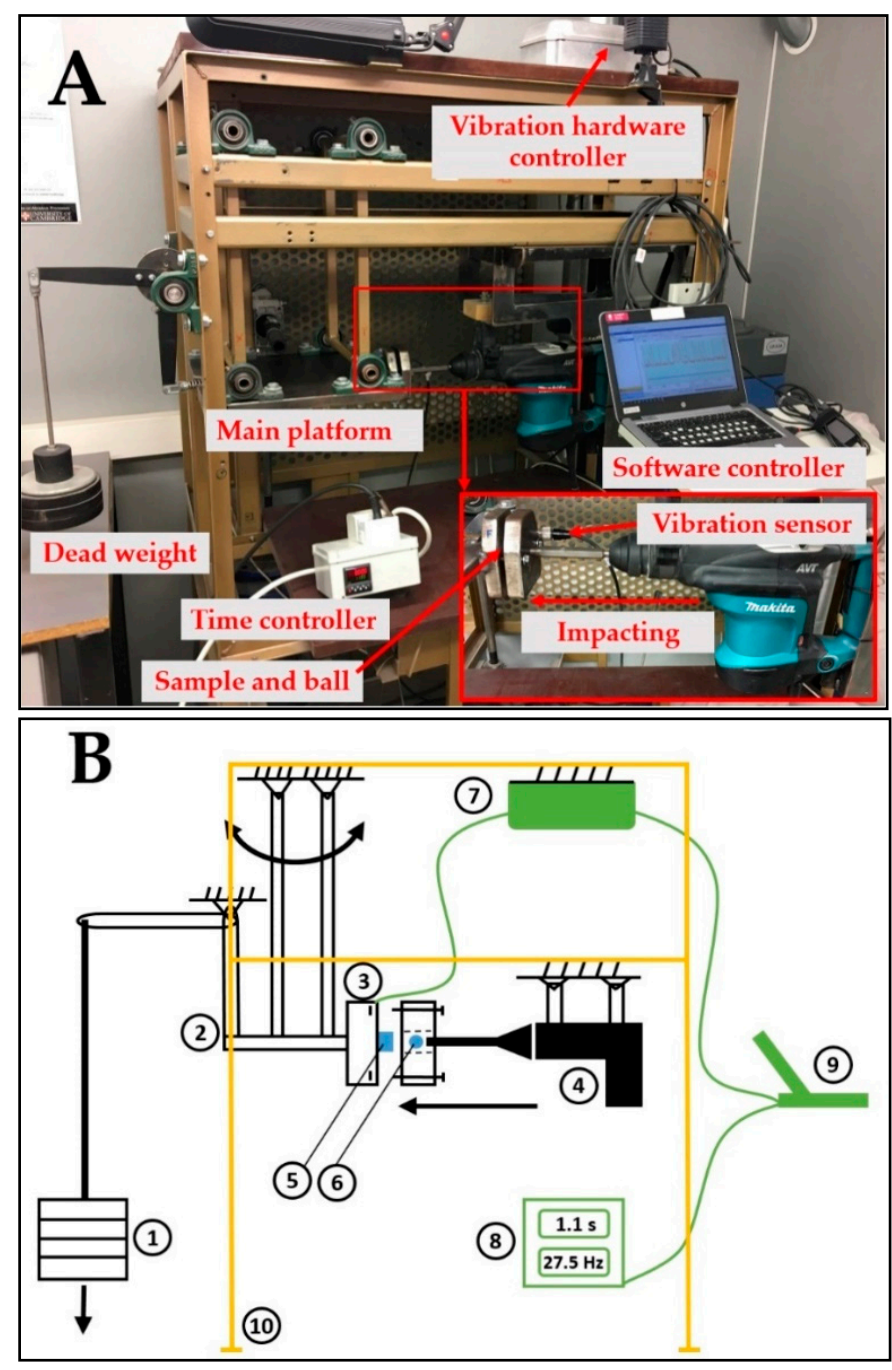

Figure 4. Impact test device: (A) Configuration, (B) schematic (1. Dead weight, 2. Main platform, 3. Holder of sample, 4. Impacting device, 5. Disk-shape sample, 6. Ball, 7. Sensor hardware, 8. Time controller, 9. Personal computer, and 10. Device structure). 

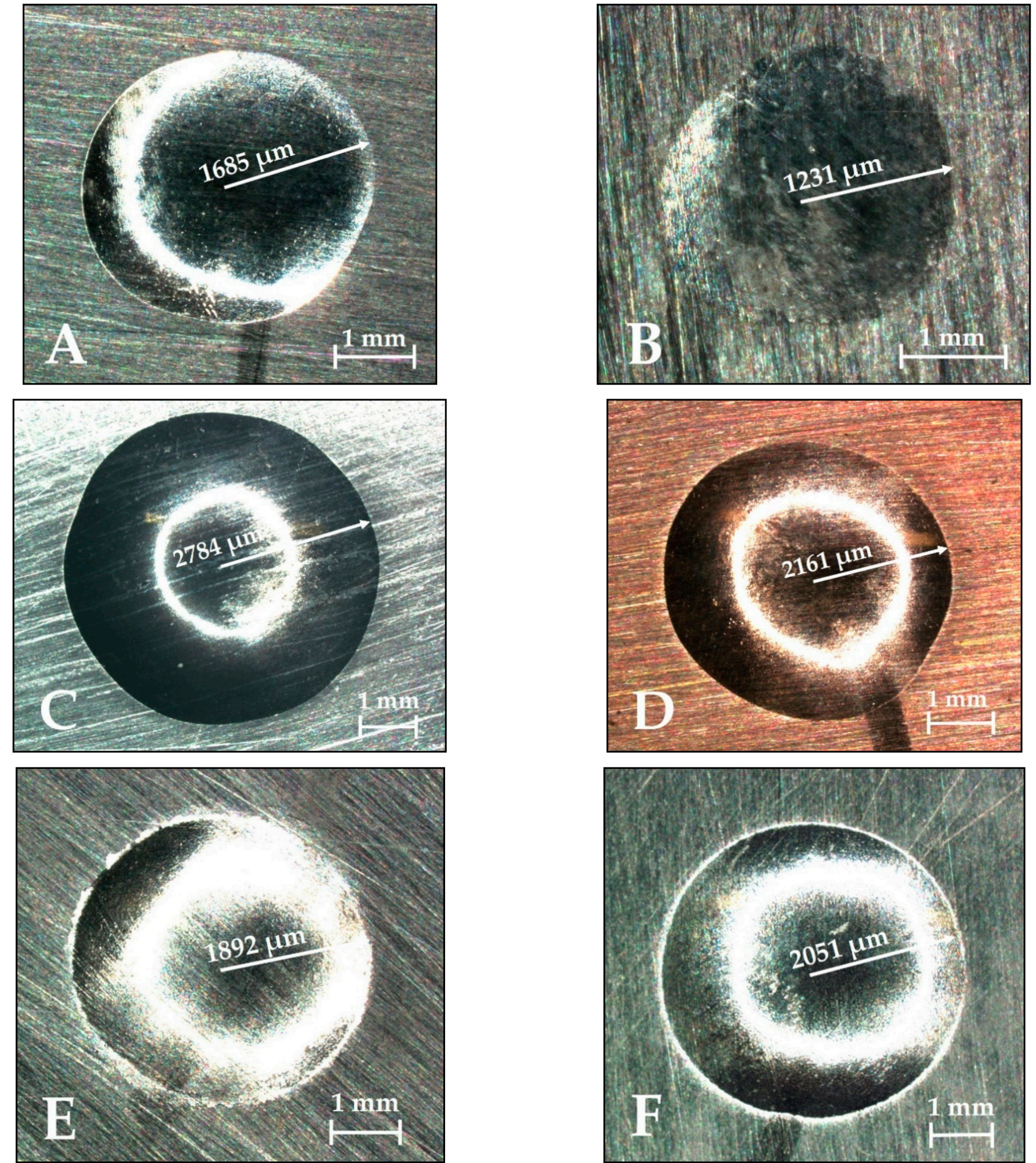

Figure 5. Optical images of the deformation sites (dimples) after impact tests: (A) Fe-based 316L, (B) $\mathrm{Ti}^{-b a s e d ~} \mathrm{Ti}_{6} \mathrm{Al}_{4} \mathrm{~V}$, (C) Al-based $\mathrm{AlSi}_{10} \mathrm{Mg}$, (D) Cu-based $\mathrm{CuNi}_{2} \mathrm{SiCr}$, (E) Co-based $\mathrm{CoCr}_{28} \mathrm{Mo}_{6}$, and (F) Ni-based Inconel718 samples. Samples had $20 \mathrm{~mm}$ diameter and $10 \mathrm{~mm}$ height. 

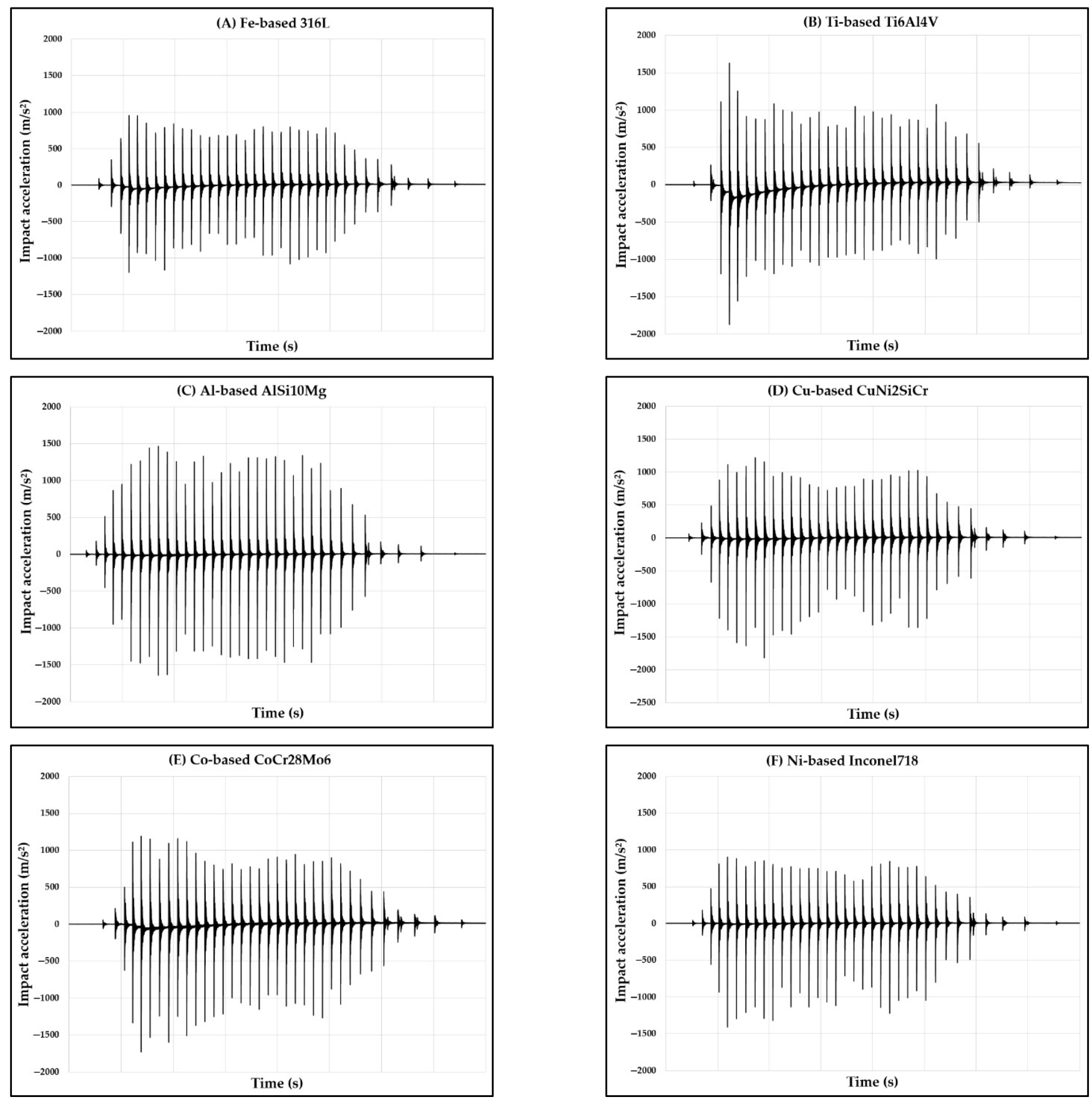

Figure 6. In situ acceleration measurements taken during impact tests with $\approx 30$ strikes: (A) Fe-based 316L, (B) Ti-based $\mathrm{Ti}_{6} \mathrm{Al}_{4} \mathrm{~V}$, (C) Al-based AlSi ${ }_{10} \mathrm{Mg}$, (D) Cu-based CuNi $2 \mathrm{SiCr}$, (E) Co-based $\mathrm{CoCr}_{28} \mathrm{Mo}_{6}$, and (F) Ni-based Inconel718 samples. 
Table 2. Metallic alloys characterization: Vickers hardness, densification after SPSing, diameter and volume of deformation indent formed, and average maximum acceleration as result of impact test.

\begin{tabular}{cccccc}
\hline Metal Alloys & $\begin{array}{c}\text { Vickers } \\
\text { Hardness }\end{array}$ & Densification & $\begin{array}{c}\text { Diameter of } \\
\text { Indent }\end{array}$ & $\begin{array}{c}\text { Volume of } \\
\text { Indent }\end{array}$ & $\begin{array}{c}\text { Average Max } \\
\text { Acceleration }\end{array}$ \\
\hline $316 \mathrm{~L}$ & $\begin{array}{c}\approx 200-240 \\
\mathrm{HV}\end{array}$ & $97.0 \%$ & $3370 \mu \mathrm{m}$ & $3.2 \mathrm{~mm}^{3}$ & $740 \mathrm{~m} / \mathrm{s}^{2}$ \\
\hline $\mathrm{Ti}_{6} \mathrm{Al}_{4} \mathrm{~V}$ & $\begin{array}{c}\approx 330-380 \\
\mathrm{HV}\end{array}$ & $91.5 \%$ & $2462 \mu \mathrm{m}$ & $1.1 \mathrm{~mm}^{3}$ & $880 \mathrm{~m} / \mathrm{s}^{2}$ \\
\hline $\mathrm{AlSi}_{10} \mathrm{Mg}$ & $\approx 70-95 \mathrm{HV}$ & $90.0 \%$ & $5568 \mu \mathrm{m}$ & $28.8 \mathrm{~mm}^{3}$ & $1190 \mathrm{~m} / \mathrm{s}^{2}$ \\
\hline $\mathrm{CuNi}_{2} \mathrm{SiCr}$ & $\begin{array}{c}\approx 135-170 \\
\mathrm{HV}\end{array}$ & $98.5 \%$ & $4322 \mu \mathrm{m}$ & $11.1 \mathrm{~mm}^{3}$ & $820 \mathrm{~m} / \mathrm{s}^{2}$ \\
\hline $\mathrm{CoCr}_{28} \mathrm{Mo} 6$ & $\begin{array}{c}\approx 260-300 \\
\mathrm{HV}\end{array}$ & $94.5 \%$ & $3784 \mu \mathrm{m}$ & $7.4 \mathrm{~mm}^{3}$ & $810 \mathrm{~m} / \mathrm{s}^{2}$ \\
\hline $\mathrm{Inconel718}$ & $\begin{array}{c}\approx 175-210 \\
\mathrm{HV}\end{array}$ & $95.5 \%$ & $4102 \mu \mathrm{m}$ & $7.7 \mathrm{~mm}^{3}$ & $750 \mathrm{~m} / \mathrm{s}^{2}$ \\
\hline
\end{tabular}

The density of metallic alloys was measured by the Archimedes immersion technique. It was expected that the densification level of each individual material would lead to a higher acceleration value ( $y$-axis, Figure 6 or Table 2). This can be achieved by higher pressure during the SPS process (100 MPa instead of $50 \mathrm{MPa}$, for example), with the expected enhancement of densification up to $99.9 \%$ and reduction of deformation site. The 316L is Fe-balanced stainless steel (known also as 1.4404), with $16 \mathrm{wt} . \% \mathrm{Cr}, 10 \mathrm{wt} . \%$ $\mathrm{Ni}$, and $2 \mathrm{wt} . \% \mathrm{Mo}$ and excellent manufacturability. Ti-balanced $\mathrm{Ti}_{6} \mathrm{Al}_{4} \mathrm{~V}$ (Grade 5), the most commonly used corrosion-resistant, high-strength, and high-toughness alloy, had 5.5-6.5 wt.\% Al and 3.5-4.5 wt.\% V. The widely used $\mathrm{AlSi}_{10} \mathrm{Mg}$ was Al-balanced, with 9-11 wt.\% Si and $0.2-0.45 \mathrm{wt} . \% \mathrm{Mg}$. AlSi ${ }_{10} \mathrm{Mg}$ is proper for aerospace application due its lightweight structure and thermal/electrical application. $\mathrm{CuNi}_{2} \mathrm{SiCr}$ with $\mathrm{Cu}$-balanced, $2 \mathrm{wt} . \% \mathrm{Ni}, 0.5 \mathrm{wt} . \% \mathrm{Si}$, and $0.1-0.8 \mathrm{wt} . \% \mathrm{Cr}$ is great for weldability and thermoelectrical conductivity. The $\mathrm{CoCr}_{28} \mathrm{Mo}_{6}$ alloy is Co-balanced, $27-30 \mathrm{wt} . \% \mathrm{Cr}$, and 5-7 wt. $\% \mathrm{Mo}$ is great for ductility, biocompatibility, and binding with hard materials. Inconel718 is Ni-balanced, with 17-21 wt.\% Cr, 2.8-3.3 wt.\% Mo, 4.7-5.5 wt.\% Nb, and 0.6-1.2 wt.\%. Ti includes a wide range of metals and is good for high-temperature applications.

The SEM micrograph of the top (intact/unpolished) and bottom (polished after removing the support), schematic of 3D printing configuration, impact test result, and acceleration measurement of 316L SLM-manufactured (As most used PBF method) are shown in Figure 7 produced by powder that is specified in Table 1. The macrostructure of the SPS-sintered 316L is depicted in Figure 7A to show the similarity of sintered and melted zone in the consolidated sample. The Realizer SLM®280 devices (made by SLM solutions AG, Lübeck, Germany) with $35 \mu$ m layer thickness, $60 \mathrm{~W}$ laser power, and $1000 \mathrm{~mm} / \mathrm{s}$ scan speed were applied for the fabrication of the solid sample illustrated in Figure 7A. Since the SLM/PBF process is supposed to be the near-net-shape (NNP) AM technology (no tooling/machining required), herein, samples were both polished by P800 sandpaper for the macrostructure comparison of SLM-manufactured and SPS-sintered 316L surface. The 316L SLM-built sample with 96\% densification was deformed and subjected impact test, resulting in its $3120 \mu \mathrm{m}$ diameter of indent, $3.1 \mathrm{~mm}^{3}$ volume of indent, and $970 \mathrm{~m} / \mathrm{s}^{2}$ average maximum acceleration. 

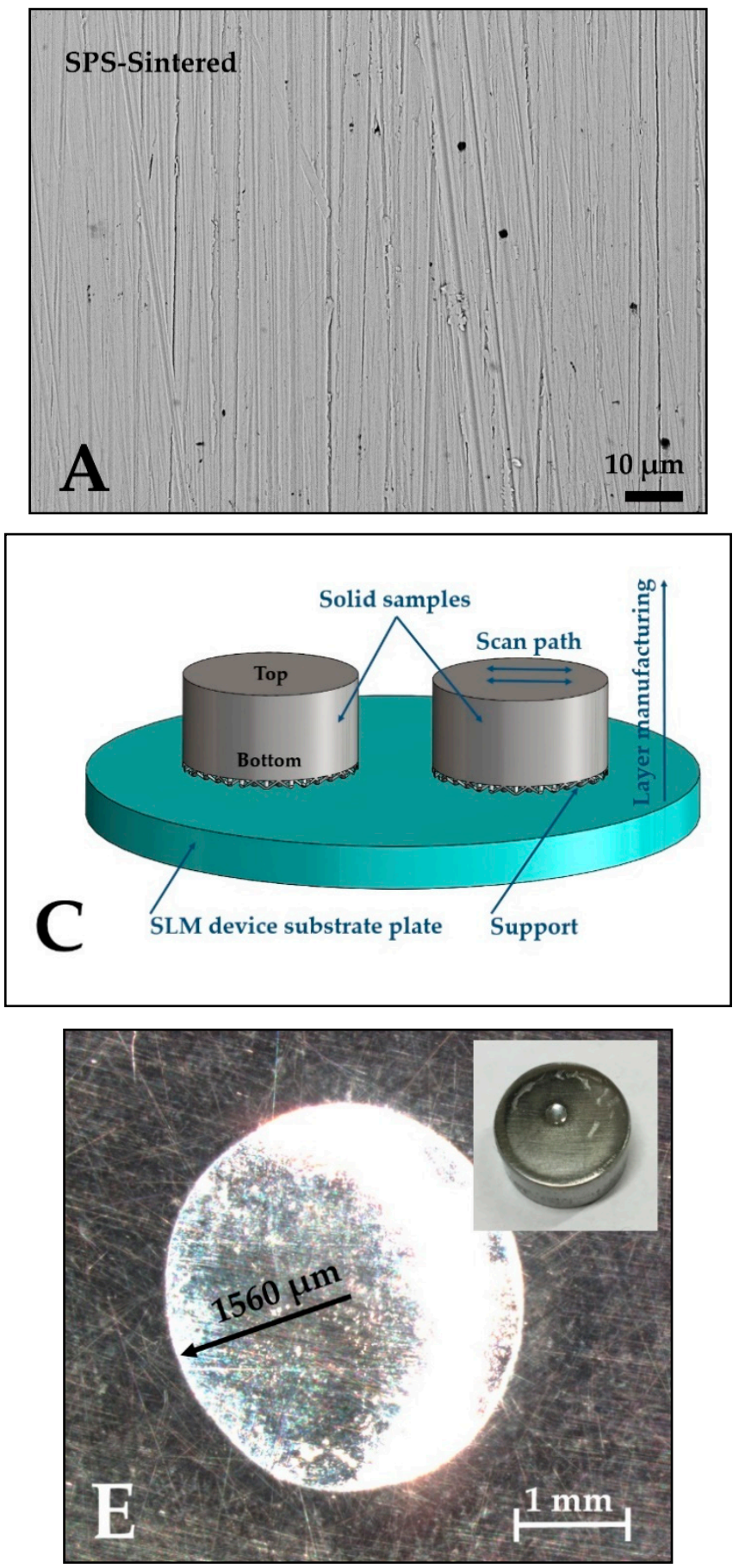
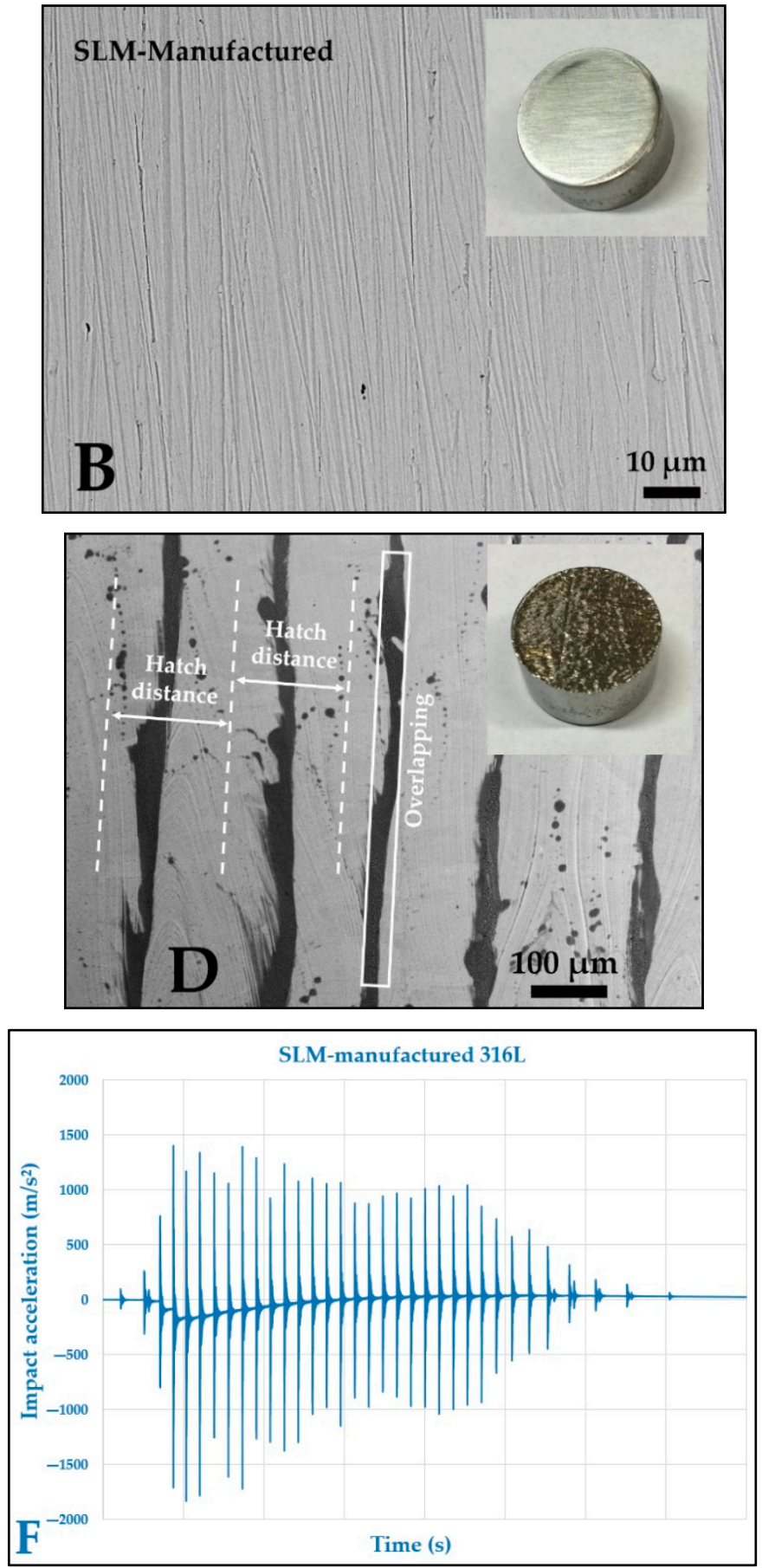

Figure 7. (A) SEM micrograph of SPS-sintered (before micrography, samples were polished with P800 wet sandpaper), (B) SEM micrograph of SLM-manufactured of 316L (after separating the support from platform/substrate, the bottom side was polished but top side remained intact), (C) schematic of SLM device (316L SLM-built sample had a $20 \mathrm{~mm}$ diameter and $10 \mathrm{~mm}$ height, similar to SPS-built samples), (D) top view of SLM-made 316L (this was the last manufactured layer of the sample, and it is possible to see the oxide layer due to overlapping and hatch distance in the path of laser scanning), (E) optical images of the deformation sites for 316L SLM-manufactured after impact tests, (F) acceleration measurement of impacts for 316L SLM-built alloy.

The TiAlN coating with $3 \mu \mathrm{m}$ thickness was prepared by the physical vapor deposition (PVD) method on the AISI 316L substrate at a temperature of $450{ }^{\circ} \mathrm{C}$ in a nitrogen atmosphere for $1 \mathrm{~h}$ and $850 \mathrm{~V}$. The $\pi-80$ PVD unit was supplied by Platit (Swiss, Grenchen, Switzerland). The lateral rotating cathode arc (LARC) method was used (Figure 8C) [32]. 
The diameter of the coated $316 \mathrm{~L}$ indent was higher than that of the uncoated $\mathrm{Ti}_{6} \mathrm{Al}_{4} \mathrm{~V}$ sample, and the indented volume of the coated 316L was lower than that of 316L without coating due to minor sliding of the ball during the impacting. The penetration diameter, penetration depth, and indented volume of $316 \mathrm{~L}$ decreased from around $1700 \mu \mathrm{m}, 500 \mu \mathrm{m}$, and $3.2 \mathrm{~mm}^{3}$ for uncoated sample to around $1500 \mu \mathrm{m}, 300 \mu \mathrm{m}$, and $1.4 \mathrm{~mm}^{3}$ for the sample with TiAlN coating subjected to the multiple impact test, respectively, as shown in Figure 8D.
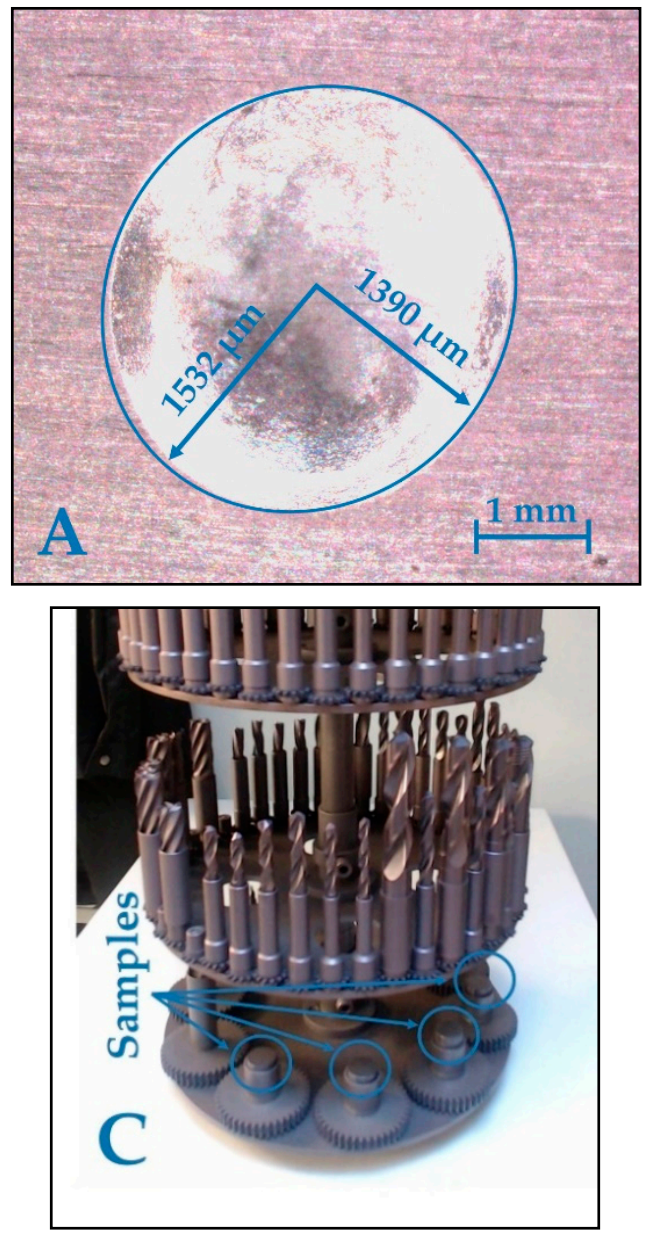

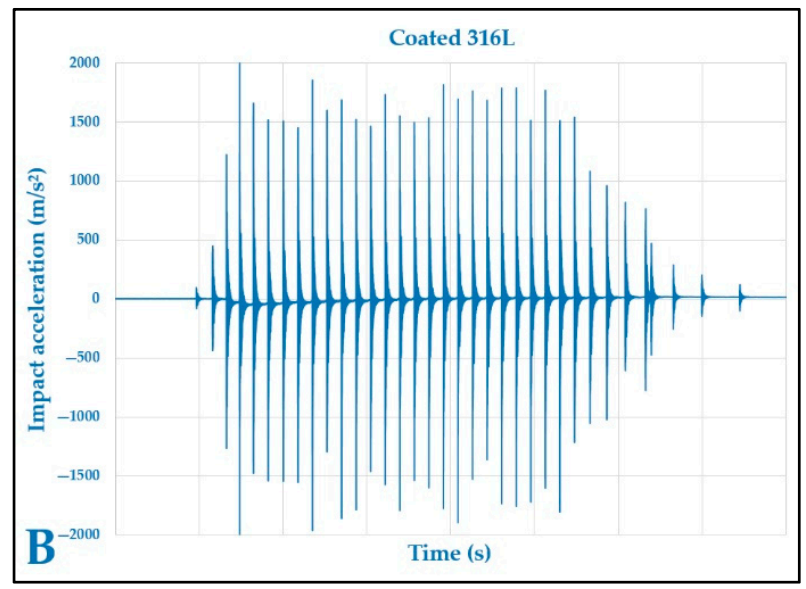

Uncoated 316L

Coated 316L

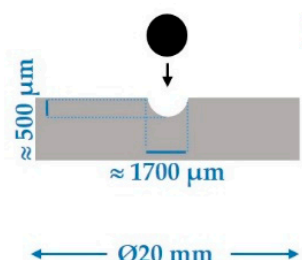

Impact ball

Sample

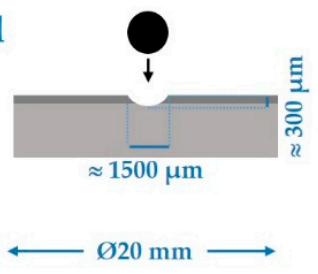

Figure 8. (A) Optical micrograph of indent and (B) acceleration measurement of impacts for coated 316L, (C) arrangement of samples in the PVD device, and (D) schematic illustration of the effect of 316L with PVD coating.

Various process parameters (for example, scan rotation) on microstructure and mechanical properties of stainless steel 316L made by L-PBF are highly effective (regardless of the density) [33]. Also, at constant laser speed, laser power has an essential role in porosity so that number of pores rises with the reduction of laser power [34]. SPS is known as a fast, homogeneous, isotropic, low-porosity, and limited grain growth process, and exhibits that pressure from 50-75 MPa has an equal effect for 316L (or other metal) alloy [35]. Through the literature, large density values with ultrafine grain size for AISI 316L have been obtained by the SPS-sintered process from ball-milled powders [36], meaning that SPS-made (PM made) samples can be compared with metal alloys made by SLM-made (L-PBF made) with high densities and less pores. This method may not apply to other ceramics or composites.

Figure 9 illustrates the average of max values of acceleration (positive peaks in Figure 6) versus indented volume. The graph shows that $316 \mathrm{~L}$ and Inconel718 had the maximum consumption of energy under the multiple impacting conditions (lowest acceleration after impact), and $\mathrm{AlSi}_{10} \mathrm{Mg}$ had minimum energy consumption (highest acceleration 
values). Based on this dynamic hardness graph, coated 316L was the material which spent all the impact energy on plastic deformation.

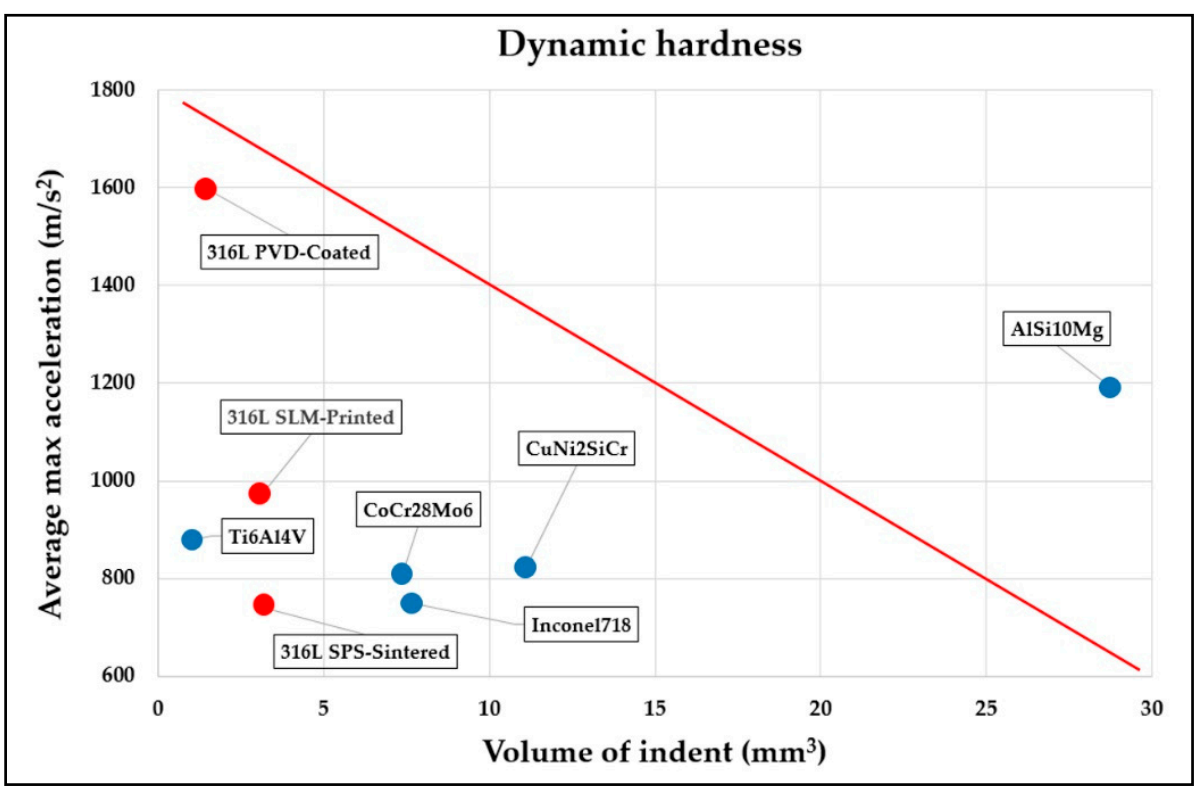

Figure 9. Dynamic hardness graph for SPS-sintered, 316L SLM-printed, and 316L PVD-coated metallic alloys. Proximity to the red line indicates the material that spent most of the energy on plastic deformation.

\section{Conclusions}

Six solid spark plasma sintered materials were successfully manufactured from gasatomized pre-alloyed powders (Fe-based $316 \mathrm{~L}$, Ti-based $\mathrm{Ti}_{6} \mathrm{Al}_{4} \mathrm{~V}, \mathrm{Al}$-based $\mathrm{AlSi}_{10} \mathrm{Mg}, \mathrm{Cu}$ based $\mathrm{CuNi}_{2} \mathrm{SiCr}$, Co-based $\mathrm{CoCr}_{28} \mathrm{Mo}_{6}$, and Ni-based Inconel718) and subjected to multiple impact tests. The aim was to present a mechanical test method for the assessment of the dynamic performance of materials. This method can be applied to materials manufactured by powder metallurgy (PM) or powder bed fusion (PBF) processes. The results show that:

The high densification rate of samples produced from spherical-shaped powders intended for PBF technology was achieved by the SPS method. The performance of these samples could be used as an indication of the best achievable properties for materials produced by the PBF approach.

In situ acceleration values recorded during multiple impact tests composed of $\approx 30 \mathrm{impacts}$ illustrate that $316 \mathrm{~L}$ and Inconel718 had the maximum consumption of energy in the contact zone during impacting (lowest acceleration after impact). $\mathrm{Ti}_{6} \mathrm{Al}_{4} \mathrm{~V}, \mathrm{CuNi} 2 \mathrm{SiCr}, \mathrm{CoCr}_{28} \mathrm{Mo}_{6}$ enabled average values, whereas AlSi10Mg had the minimum energy consumption.

The impact energy consumed did not result in the respective size of indent (extent of plastic deformation). The largest-to-smallest size indents were observed for $\mathrm{AlSi}_{10} \mathrm{Mg}$ $\mathrm{CuNi}_{2} \mathrm{SiCr}$ - Inconel718- $\mathrm{CoCr}_{28} \mathrm{Mo}_{6}-316 \mathrm{~L}-\mathrm{Ti}_{6} \mathrm{Al}_{4} \mathrm{~V}$. It was possible to identify two materials that behaved differently from others. $\mathrm{AlSi}_{10} \mathrm{Mg}$ consumed less energy during impacts while it had the largest imprint. On the other hand, 316L consumed the most energy while had the smallest imprint.

The application of PVD coating to the 316L significantly reduced the consumption of energy during the impact while the size of the indent was reduced slightly. The diameter and volume of the indent were reduced and improved by $15 \%$ and $56 \%$, respectively, for the coated 316L (with $3 \mu \mathrm{m}$ TiAlN coating) in comparison with uncoated 316L.

The wear impact result was approximately equal for PBF-manufactured ( $35 \mu \mathrm{m}$ layer thickness, $60 \mathrm{~W}$ laser power, and $1000 \mathrm{~mm} / \mathrm{s}$ scan speed) and SPS-sintered (50 MPa pressure, $100{ }^{\circ} \mathrm{C} / \mathrm{min}$ heating rate, $1000{ }^{\circ} \mathrm{C}$ sintering temperature, and 5 min dwelling time) $316 \mathrm{~L}$ stainless steel with identical appearance (96-97\% densification, $20 \mathrm{~mm}$ diameter and $10 \mathrm{~mm}$ 
height). This means that we can apply these modern powder metallurgy methods for the assessment of novel additive manufacturing processes.

Author Contributions: Conceptualization, R.R., M.A. and K.G.P.; methodology, R.R. and M.A.; investigation, R.R.; writing-original draft preparation, R.R.; writing-review and editing, M.A. and K.G.P.; supervision, M.A.; funding acquisition, M.A. and K.G.P. All authors have read and agreed to the published version of the manuscript.

Funding: This research was funded by Estonian Ministry of Education and Research, and Slovenian Research Agency Program grant number SS427, M-ERA.NET Duracer ETAG18012, and P2-0263.

Institutional Review Board Statement: Not applicable.

Informed Consent Statement: Not applicable.

Data Availability Statement: This study did not report any supporting data.

Acknowledgments: The authors would like to thank Heinar Vagiström for the help with PVD coating of samples.

Conflicts of Interest: The authors declare no conflict of interest.

\section{References}

1. Saheb, N.; Iqbal, Z.; Khalil, A.; Hakeem, A.S.; Al-Aqeeli, N.; Laoui, T.; Al-Qutub, A.; Kirchner, R. Spark Plasma Sintering of Metals and Metal Matrix Nanocomposites: A Review. J. Nanomater. 2012, 2012, 983470. [CrossRef]

2. Chawake, N.; Pinto, L.D.; Srivastav, A.K.; Akkiraju, K.; Murty, B.S.; Kottada, R.S. On Joule heating during spark plasma sintering of metal powders. Scr. Mater. 2014, 93, 52-55. [CrossRef]

3. Singh, N.; Hameed, P.; Ummethala, R.; Manivasagam, G.; Prashanth, K.G.; Eckert, J. Selective laser manufacturing of Ti-based alloys and composites: Impact of process parameters, application trends, and future prospects. Mater. Today Adv. 2020, 8, 100097. [CrossRef]

4. Li, R.; Shi, Y.; Wang, Z.; Wang, L.; Liu, J.; Jiang, W. Densification behavior of gas and water atomized 316L stainless steel powder during selective laser melting. Appl. Surf. Sci. 2010, 256, 4350-4356. [CrossRef]

5. Rahmani, R.; Brojan, M.; Antonov, M.; Prashanth, K.G. Perspectives of metal-diamond composites additive manufacturing using SLM-SPS and other techniques for increased wear-impact resistance. Int. J. Refract. Met. Hard Mater. 2020, 88, 105192. [CrossRef]

6. Facchini, L.; Magalini, E.; Robotti, P.; Molinari, A.; Höges, S.; Wissenbach, K. Ductility of a Ti-6Al-4V alloy produced by selective laser melting of pre-alloyed powders. Rapid Prototyp. J. 2010, 16, 450-459. [CrossRef]

7. Rahmani, R.; Antonov, M.; Kollo, L.; Holovenko, Y.; Prashanth, K.G. Mechanical Behavior of $\mathrm{Ti}_{6} \mathrm{Al}_{4} \mathrm{~V} \mathrm{Scaffolds} \mathrm{Filled} \mathrm{with} \mathrm{CaSiO}_{3}$ for Implant Applications. Appl. Sci. 2019, 9, 3844. [CrossRef]

8. Rahmani, R.; Rosenberg, M.; Ivask, A.; Kollo, L. Comparison of mechanical and antibacterial properties of $\mathrm{TiO}_{2} / \mathrm{Ag}_{\mathrm{g}}$ ceramics and Ti6Al4V-TiO $/$ Ag composite materials using combining SLM-SPS techniques. Metals 2019, 9, 874. [CrossRef]

9. Ngo, T.D.; Kashani, A.; Imbalzano, G.; Nguyen, K.T.Q.; Hui, D. Additive manufacturing (3D printing): A review of materials, methods, applications and challenges. Compos. Part B Eng. 2018, 143, 172-196. [CrossRef]

10. Huang, S.H.; Liu, P.; Mokasdar, A.; Hou, L. Additive manufacturing and its societal impact: A literature review. Int. J. Adv. Manuf. Technol. 2013, 67, 1191-1203. [CrossRef]

11. Thijs, L.; Verhaeghe, F.; Craeghs, T.; Humbeeck, J.V.; Kruth, J.-P. A study of the microstructural evolution during selective laser melting of Ti-6Al-4V. Acta Mater. 2010, 58, 3303-3312. [CrossRef]

12. Yadroitsev, I.; Bertrand, P.; Smurov, I. Parametric analysis of the selective laser melting process. Appl. Surf. Sci. 2007, 253, 8064-8069. [CrossRef]

13. Kempen, K.; Thijs, L.; Van Humbeeck, J.; Kruth, J.-P. Mechanical Properties of AlSi ${ }_{10}$ Mg Produced by Selective Laser Melting. Phys. Procedia 2012, 39, 439-446. [CrossRef]

14. Tiberto, D.; Klotz, U.E.; Held, F.; Wolf, G. Additive manufacturing of copper alloys: Influence of process parameters and alloying elements. Mater. Sci. Technol. 2018, 35, 969-977. [CrossRef]

15. Hedberg, Y.S.; Qian, B.; Shen, Z.; Virtanen, S.; Wallinder, I.O. In vitro biocompatibility of CoCrMo dental alloys fabricated by selective laser melting. Dent. Mater. 2014, 30, 525-534. [CrossRef]

16. Available online: https://scheftner.dental/starbond-cos-powder-en.html (accessed on 10 January 2021).

17. Available online: https://www.hoganas.com/en/powder-technologies/surface-coating/rockit-abrasive-wear (accessed on 10 January 2021).

18. Trosch, T.; Strößner, J.; Völkl, R.; Glatzel, U. Microstructure and mechanical properties of selective laser melted Inconel 718 compared to forging and casting. Mater. Lett. 2016, 164, 428-431. [CrossRef]

19. Rahmani, R.; Antonov, M.; Kamboj, N. Modelling of impact-abrasive wear of ceramic, metallic, and composite materials. Proc. Est. Acad. Sci. 2019, 68, 191-197. [CrossRef] 
20. Rahmani, R.; Antonov, M.; Kollo, L. Wear Resistance of (Diamond-Ni)- $\mathrm{Ti}_{6} \mathrm{Al}_{4} \mathrm{~V}$ Gradient Materials Prepared by Combined Selective Laser Melting and Spark Plasma Sintering Techniques. Adv. Tribol. 2019, 2019, 5415897. [CrossRef]

21. Rahmani, R.; Antonov, M. Axial and torsional buckling analysis of single- and multi-walled carbon nanotubes: Finite element comparison between armchair and zigzag types. SN Appl. Sci. 2019, 9, 1134. [CrossRef]

22. Available online: https://www.slm-solutions.com/en/products/accessories-consumables/slmr-metal-powder (accessed on 10 January 2021).

23. Available online: https://www.tls-technik.de/en/products.html (accessed on 10 January 2021).

24. Available online: https://en.c-semt.com/metal-powder (accessed on 10 January 2021).

25. Available online: http://www.fct-systeme.de/en/ (accessed on 10 January 2021).

26. Rahmani, R.; Brojan, M.; Antonov, M. Lightweight 3D printed $\mathrm{Ti}_{6} \mathrm{Al}_{4} \mathrm{~V}-\mathrm{AlSi}_{10} \mathrm{Mg}$ hybrid composite for impact resistance and armor piercing shielding. J. Mater. Res. Technol. 2020, 9, 13842-13854. [CrossRef]

27. Antonov, M.; Veinthal, R.; Yung, D.L.; Katusin, D.; Hussainova, I. Mapping of impact abrasive wear performance of WC-Co cemented carbides. Wear 2015, 332-333, 971-978. [CrossRef]

28. Rahmani, R.; Antonov, M.; Kollo, L. Selective Laser Melting of Diamond-Containing or Postnitrided Materials Intended for Impact-Abrasive Conditions: Experimental and Analytical Study. Adv. Mater. Sci. Eng. 2019, 2019, 4210762. [CrossRef]

29. Kamboj, N.; Kazantseva, J.; Rahmani, R.; Rodríguez, M.A.; Hussainova, I. Selective laser sintered bio-inspired silicon-wollastonite scaffolds for bone tissue engineering. Mater. Sci. Eng. C 2020, 116, 111223. [CrossRef] [PubMed]

30. Kamboj, N.; Rodríguez, M.A.; Rahmani, R.; Prashanth, K.G.; Hussainova, I. Bioceramic scaffolds by additive manufacturing for controlled delivery of the antibiotic vancomycin. Proc. Est. Acad. Sci. USA 2019, 68, 185-190. [CrossRef]

31. Holovenko, Y.; Kollo, L.; Saarna, M.; Rahmani, R.; Soloviova, T.; Antonov, M.; Prashanth, K.G.; Cygan, S.; Veinthal, R. Effect of lattice surface treatment on performance of hardmetal-titanium interpenetrating phase composites. Int. J. Refract. Met. Hard Mater. 2020, 86, 105087. [CrossRef]

32. Baronins, J.; Antonov, M.; Bereznev, S.; Raadik, T.; Hussainova, I. Raman Spectroscopy for Reliability Assessment of Multilayered AlCrN Coating in Tribo-Corrosive Conditions. Coatings 2018, 8, 229. [CrossRef]

33. Leicht, A.; Yu, C.H.; Luzin, V.; Klement, U.; Hryha, E. Effect of scan rotation on the microstructure development and mechanical properties of 316L parts produced by laser powder bed fusion. Mater. Charact. 2020, 163, 110309. [CrossRef]

34. Garlea, E.; Choo, H.; Sluss, C.C.; Koehler, M.R.; Bridges, R.L.; Xiao, X.; Ren, Y.; Jared, B.H. Variation of elastic mechanical properties with texture, porosity, and defect characteristics in laser powder bed fusion 316L stainless steel. Mater. Sci. Eng. A 2019, 763, 138032. [CrossRef]

35. Marnier, G.; Keller, C.; Noudem, J.; Hug, E. Functional properties of a spark plasma sintered ultrafine-grained 316L steel. Mater. Design 2014, 63, 633-640. [CrossRef]

36. Keller, C.; Tabalaiev, K.; Marnier, G.; Noudem, J.; Sauvage, X.; Hug, E. Influence of spark plasma sintering conditions on the sintering and functional properties of an ultra-fine grained 316L stainless steel obtained from ball-milled powder. Mater. Sci. Eng. A 2016, 665, 125-134. [CrossRef] 